\title{
The mafic intrusive magmatism from the Paraná LIP constrained by new U- $P b$ baddeleyite ID-TIMS ages
}

\author{
BRENDA CHUNG ROCHA ${ }^{1}$, SEAN P GAYNOR ${ }^{2}$, \\ VALDECIR DE ASSIS JANASI $^{1}$, JOSHUA H.F.L. DAVIES ${ }^{3}$, \\ LUANA MOREIRA FLORISBAL ${ }^{4}$, BRENO LEITÃO \\ WAICHEL ${ }^{4}$ AND PROF. URS SCHALTEGGER, PHD ${ }^{2}$ \\ ${ }^{1}$ Instituto de Geociências - Universidade de São Paulo \\ ${ }^{2}$ University of Geneva \\ ${ }^{3}$ Université de Québec à Montréal \\ ${ }^{4}$ Universidade Federal de Santa Catarina \\ Presenting Author: brenda.rocha@usp.br
}

A causal and temporal link between large igneous provinces (LIPs), global climate disturbances and mass extinctions has been demonstrated for several Phanerozoic LIPs. Despite this well-established link, the environmental effects associated with the Cretaceous Paraná-Etendeka LIP, one of the world's largest LIPs, are seemingly less catastrophic. The only global event at a similar time to the LIP is a minor oceanic anoxic event (OAE) during the Valanginian. However recently, the temporal link between the main volcanism from the Paraná LIP (Brazilian) and the Valanginian event has been revised, at least for the silicic parts of the volcanic province. The stratigraphically oldest silicic magmas were shown to have erupted very rapidly at ca. 133.6 $\mathrm{Ma}$ and to postdate the Valanginian event by $\sim 1 \mathrm{Ma}$ [1]. However, the role of mafic intrusions in the Paraná LIP remains unclear due to limited high-precision geochronology.

Here, we present new high-precision baddeleyite U-Pb IDTIMS data from mafic intrusive rocks: (i) a high-Ti-Sr basaltic dyke sample from the Florianópolis Dyke Swarm (FDS), interpreted as a feeder to the Urubici lavas, one of the earliest eruptive phases of the Paraná, and (ii) a high-Ti basaltic sill intruded higher in the volcanic pile cropping out west of the FDS. Our new preliminary baddeleyite ages are younger than silicic volcanism, and overlap with the youngest published ${ }^{40} \mathrm{Ar}-{ }^{39} \mathrm{Ar}$ ages from high-Ti basalt sills from Northern Paraná [2]. If dating the magmatic crystalization, these ages would indicate an up to $2 \mathrm{Myr}$ duration of intrusive magmatism in this part of the Province. However, they can also reflect $\mathrm{Pb}$ loss. These new dates place additional temporal constraints on the Paraná LIP, and are consistent with the interpretation that the Paraná LIP volcanism did not trigger the Valanginian event.

[1] Rocha et al (2020) Geology 48, 1174-1178. [2] Ernesto et al (1999) Journal of Geodynamics 28, 321-340. 